Ewa Baniowska-Kopacz

ORCID: https://orcid.org/0000-0001-8091-6315

Instytut Archeologii i Etnologii

Polska Akademia Nauk /Kraków

\title{
„Nowohuckie podwórka” - od podwórka. Spojrzenie etnologa
}

\section{"The backyards of Nowa Huta" as seen from the backyard. An ethnologist's view}

\begin{abstract}
The article discusses the topic of spaces adjacent to houses in the oldest area of Nowa Huta, a district of Cracow established in the middle of the $20^{\text {th }}$ century. These spaces are mostly courtyards, and especially household gardens located in those courtyards, e.g. at the front walls of houses, between the entryways or in the backyards, directly under apartment windows. Such gardens - separated spaces established and farmed by the residents of Nowa Huta - provide a basis for presenting the local community. The article constitutes an attempt at analysing the community through those domesticated patches of land, transformed by the residents' actions into a place, i.e. a tamed space endowed with individual features and constituting a part of the life of individual residents and the community as a whole.
\end{abstract}

Key words: space, place, residence, rootedness, backyard, Nowa Huta gardens, Cracow-Nowa Huta, Poland

W artykule podjęto temat przydomowych przestrzeni znajdujących się w obrębie najstarszej części Nowej Huty. Chodzi tu o podwórka, a przede wszystkim znajdujące się w ich granicach ogródki, założone i uprawiane przez lokatorów tuż przy ścianach frontowych, pomiędzy bramami wejściowymi do domów, jak również na ich tyłach, bezpośrednio pod oknami mieszkań. Te nowohuckie ogródki, będące przestrzeniami wydzielonymi, są pretekstem do ukazania społeczności lokalnej. Artykuł jest próbą spojrzenia na nią przez pryzmat tych udomowionych skrawków ziemi, przekształconych przez podejmowane działania w miejsce, czyli przestrzeń oswojoną, obdarzoną indywidualnym rysem, wplecioną w życie jednostek i ogółu.

Słowa kluczowe: przestrzeń, miejsce, zamieszkiwanie, zakorzenienie, podwórko, nowohuckie ogródki, Kraków-Nowa Huta, Polska

Odebrano / Received: 31.01.2019

Zaakceptowano / Accepted: 27.08.2019 
Sformułowanie „Nowohuckie podwórka” nawiązuje do tytułu krótkiego filmu", prezentowanego w krakowskiej komunikacji miejskiej, a także możliwego do obejrzenia w internecie na YouTube ${ }^{2}$. Film zaczyna się od ukazania z lotu ptaka Placu Centralnego ${ }^{3}$ i Alei Róż w Nowej Hucie. Te pierwsze kadry poprzedza „najazd” kamery na Łąki Nowohuckie, bezpośrednio przylegające (poprzez Al. Jana Pawła II) do Placu Centralnego. Następnie widzimy - nadal z ptasiej perspektywy - rozplanowanie ulic, bloków, tworzących gwiaździsty układ ${ }^{4}$ urbanistyczny najstarszej części Nowej Huty. Wewnętrzne przestrzenie wypełnione są zielenią rozrosłych drzew i krzewów. Kolejne kadry przedstawiają już z pozycji przechodnia poszczególne podwórka. Rolę filmowego przewodnika pełni młoda kobieta. Przechadzając się, ogląda i równocześnie zwraca uwagę widza na fasady domów, ich otoczenie wypełnione zieleńcami z drzewami, krzewami i kwiatami, a także place zabaw, „leciwe” już trzepaki, suszarki do wieszania prania. Kieruje wzrok na zadbane ogródki przed blokami i kwiaty w doniczkach (pelargonie krakowiaki) ustawione na zewnętrznych parapetach, osłoniętych drewnianymi płotkami. Widzimy także ludzi, zapewne mieszkańców, rozmawiających ze sobą sąsiadów, przedstawicieli starszego pokolenia, ale także osoby w średnim wieku i dzieci. Dominujące jednak są obrazy zieleni, kwitnące hortensje, „pachnące groszki”, róże i inne rośliny. Film kończą kadry ukazujące ponownie widok z lotu ptaka.

Film został zrealizowany latem, przy pięknej słonecznej pogodzie, co dało możliwość ukazania w malowniczej aurze głównych i niewątpliwych atutów tej części Nowej Huty - ciekawego układu urbanistycznego objętego ochroną konserwatorską ${ }^{5}$ oraz

1 Jak zaznaczył w rozmowie Maciej Grzyb powstał on jako postprodukcja jednego z odcinków cyklicznego programu informacyjnego UMK realizowanego we współpracy z Telewizją Kraków. Wspomniany cykl nosi tytuł „Krakow.pl dodaj do ulubionych” i jest prezentowanych w internecie (Krakow.pl dodaj do ulubionych, 04.01.2019). Materiały, które wykorzystano do zmontowania filmu prezentowanego w krakowskim MPK były sfilmowane do 11. odcinka wspomnianego cyklu, poświęconego m.in. projektowi „Spotkajmy się na podwórku”. W tym miejscu pragnę podziękować Panu Maciejowi Grzybowi, zastępcy Dyrektora w Wydziale Komunikacji Społecznej Urzędu Miasta Krakowa, za przeprowadzoną rozmowę i pomoc w skompletowaniu dokumentów UM Krakowa związanych z problematyką poruszaną $\mathrm{w}$ artykule.

2 Film został opublikowany na YouTube 29.09.2017 roku; Kraków.pl dodaj do ulubionych - nowohuckie podwórka, 23.01.2019.

3 Pełna nazwa placu brzmi Plac Centralny im. Ronalda Reagana. Obecne brzmienie nazwy obowiązuje od 2004 roku, mieszkańcy jednak najczęściej ograniczają się do pierwszego członu nazwy - Plac Centralny.

4 Karpińska 2018, s. 24.

5 „Ochronie podlega zarówno układ miasta [Nowej Huty - E.B.K.], jak i urbanistyczne rozwiązania poszczególnych jego części składowych. W zakresie kompozycji urbanistycznej kwestią nadrzędną jest utrzymanie status quo, z możliwością dopuszczenia takich zmian, które nie przeczą założeniom projektowym, przywracają wartości zagubione, ewentualnie niezrealizowane” (Komorowski 2017, s. 159). Zob. także Myczkowski, Siwek 2017 oraz dokumenty Urzędu Miasta Krakowa w tym plan utworzenia Parku Kulturowego Nowa Huta (Park Kulturowy Nowa Huta, 14.01.2019). 
wewnętrznych przestrzeni, które w ciągu lat wypełniły się zróżnicowaną roślinnością, realizując założenie architektów - twórców „miasta ogrodu”.

Filmowa przewodniczka, rozglądając się z zaciekawieniem, mimowolnie zaznacza swoją odrębność wobec przestrzeni, w której w tym momencie przebywa ${ }^{7}$. Postrzegamy te miejsca z perspektywy osoby, która przechodzi, niespiesznie mija je, a uśmiech na twarzy sugeruje zadowolenie i pozytywne do nich nastawienie.

Wielokrotnie oglądałam ten film i zawsze wywoływał także u mnie uśmiech. Był on dla mnie wspomnieniem czasu, kiedy ta perspektywa przechodnia/spacerowicza po prezentowanych w filmie miejscach towarzyszyła także mnie samej, stając się jednym z ważniejszych elementów decydujących o wyborze przyszłego miejsca zamieszkania. Priorytetem stała się dla mnie historyczna, tzw. stara Nowa Huta, mimo że, będąc nowohucianką z urodzenia, wiele lat swojego życia spędziłam w powstałych w późniejszych latach częściach tzw. wielkiej Nowej Huty. Po kilku latach mieszkania i zapoznawania się z przestrzenią, a nade wszystko z ludźmi, bliższymi i dalszymi sąsiadami, zyskałam perspektywę określaną na gruncie etnologii jako emic ${ }^{9}$.W tym stosunkowo szybkim zapoznawaniu się z ludźmi - moimi sąsiadami i otoczeniem bardzo pomocny okazał się nasz czworonożny członek rodziny - Uszatek, kocur, którego los sprowadził na stałe do naszego domu. $Z$ dawnych czasów kociego życia na wolności pozostało Uszatkowi jedno - konsekwentnie egzekwowany od nas, jego opiekunów,

${ }^{6}$ W gronie specjalistów urbanistów, architektów i konserwatorów zabytków jest jednakże obecne przeświadczenie o niekontrolowanym (wskutek zaniedbań wielu lat) rozroście roślinności, która zdominowała niektóre przestrzenie starej części Nowej Huty (por. Komorowski 2017).

Takie też było zamierzenie twórców tego filmu (wywiad z M. Grzybem).

8 W dyskursie zarówno urzędników - np. radnych, ale także np. agentów nieruchomości jak i mieszkańców tych terenów, pojawia się rozróżnienie na te dwa zakresy znaczeniowe i sposoby postrzegania Nowej Huty. Pierwotnie miała być ona samodzielnym i niezależnym miastem zbudowanym od podstaw na północnym wschodzie Krakowa. W 1951 roku gminę Mogiła, na której terenach wznoszono zaprojektowane miasto, włączono do Krakowa i utworzono nową dzielnicę pod nazwą Nowa Huta. Dzielnica rozbudowywała się, bardzo szybko stając się największą i najludniejszą częścią Krakowa. W 1990 wprowadzono nowy podział administracyjny miasta, wydzielając na dotychczasowym obszarze Nowej Huty pięć dzielnic samorządowych. Są to Dzielnica XIV Czyżyny, Dzielnica XV Mistrzejowice, Dzielnica XVI Bieńczyce, dzielnica XVII Wzgórza Krzesławickie i Dzielnica XVIII Nowa Huta. W skład ostatniej wchodzi najstarsza część Nowej Huty, często określana starą Hutą, starą Nową Hutą lub historyczną Nową Hutą (Park Kulturowy Nowa Huta 2017, s. 4). Sformułowanie wielka Nowa Huta obejmuje natomiast wszystkie pięć dzielnic. Należy jednak zauważyć, że wszystkie one - zwłaszcza w ostatnim dziesięcioleciu - bardzo rozbudowują się i są zasiedlane przez osoby często nie odczuwające związku ani z Nową Hutą, ani też nie są świadome przeszłości zamieszkiwanych miejsc. Dobrym przykładem może być zasłyszane w komunikacji miejskiej stwierdzenie ,jestem na Białucha”. Białucha jest nazwą przystanku tramwajowego, który swoją nazwę zawdzięcza płynącej w pobliżu rzece Białusze (która jest tak nazywana tylko na krótkim odcinku - w swoim dolnym biegu, na obszarze Krakowa, a oficjalna nazwa to Prądnik). Nazwa przystanku nie wywodzi się od nazwiska, a można by tak sądzić po zasłyszanej wypowiedzi.

9 Burszta 1987, s. 74-75; Bielecka-Prus 2011, s. 67-69. 
codzienny długi spacer. Wspominam o tych faktach, ponieważ codzienne spacery pozwoliły mi w bardzo krótkim czasie dokładnie, „od podszewki” ${ }^{10}$, poznać teren, który wybrałam na swoje miejsce zamieszkania. Pomogły mi zobaczyć ukazane w filmie podwórka od drugiej strony - tej nieoficjalnej, niewidocznej dla przygodnego przechodnia. Umożliwiły mi także nawiązanie miłych lub mniej miłych kontaktów sąsiedzkich.

W centrum mojej uwagi w tym artykule pozostają przydomowe przestrzenie bezpośrednio przylegające do domów, w terminologii urzędowej ${ }^{11}$ określane przedogródkami. Są to obszary pomiędzy wejściami do bloków. W analizowanych przypadkach występują one także z drugiej strony domów, bezpośrednio pod oknami mieszkań. Będę je określać po prostu mianem ogródków, tak jak zresztą mówią o nich mieszkańcy tych terenów. Te nowohuckie ogródki, będące strefami wydzielonymi, stały się dla mnie pretekstem do ukazania lokalnej społeczności, czterech najstarszych osiedli nowohuckich Wandy, Willowego, Na Skarpie i Młodości ${ }^{12}$. Spróbuję spojrzeć na nią przez pryzmat tych udomowionych skrawków ziemi, przekształconych przez podejmowane działania w miejsce, czyli przestrzeń oswojoną, znaną, wewnętrzną, obdarzoną indywidualnym rysem, wplecioną w życie jednostek i społeczności ${ }^{13}$.

Warto $\mathrm{w}$ tym miejscu zwrócić uwagę na wzajemne oddziaływanie, człowieka i przestrzeni (miejsca), które Aleksander Wallis określa jako „(...) jedno z najbardziej doniosłych w kulturze sprzężeń zwrotnych”14. Również Hanna Buczyńska-Garewicz, zwraca uwagę że: „Ani miejsce, ani człowiek w nim mieszkający nie są pierwsze wobec drugiego, istotą obu jest wzajemne wspólistnienie i współformowanie”15. Możliwość odczytywania procesu zasiedlania, zamieszkiwania i poznawania społeczności poprzez analizowane ogródki są tu dla mnie najistotniejsze.

Moje codzienne obserwacje oraz przeprowadzone badania ${ }^{16}$ wskazują na znaczącą stabilność zamieszkania na obserwowanym terenie. W większości przypadków osoby,

${ }^{10}$ Spacer z kotem na smyczy wygląda nieco inaczej niż spacer z psem. Po pierwsze, to kot wyznacza trasę. Po drugie, kot zazwyczaj chodzi wzdłuż ścian, ogrodzeń, niezwykle rzadko chodzi „ludzkimi” szlakami, np. chodnikiem. Wynika to z tego, że jego celem jest zidentyfikowanie miejsc przebywania innych kotów, a później systematyczna (codzienna) kontrola terytorium i zaznaczanie na niej swojej obecności, co wiąże się z zacieraniem tropów innych kotów. Zatem spacer prowadzi ścieżkami, którymi zazwyczaj nie chodzą ludzie, i jeśli nie są oni mieszkańcami danego bloku najczęściej nie są świadomi tego, co skrywa bujna roślinność.

${ }^{11}$ Termin ten jest stosowany przez pracowników Zarządu Zieleni Miejskiej w Krakowie.

12 Osiedla Wandy i Willowe wznoszono w latach 1949-1950, Na Skarpie 1950-52, Młodości 1954-1959 (Karpińska 2018, s. 26-27; Wiśniewski 2018, s. 37, s. 39).

${ }_{13}$ Augé 2010, s. 34.

${ }^{14}$ Wallis 1979, s. 13.

${ }^{15}$ Buczyńska-Garewicz 2006, s. 6.

${ }^{16} \mathrm{Na}$ przedstawionym w artykule terenie mieszkam od 2012 roku. Jednakże dopiero od wiosny 2014 roku (wtedy w naszym domu pojawił się Uszatek - wówczas 8-letni kocur) systematycznie i coraz bardziej 
z którymi rozmawiałam, osiadły tu kilkanaście i więcej lat temu ${ }^{17}$. W tym gronie należy wymienić nielicznych już, ze względu na upływ czasu, mieszkańców, którzy należą do grupy pierwszych osadników. Młodsi, często są ich potomkami i reprezentują już drugie lub trzecie pokolenie. Swoisty - jak na miasto - fakt słabej rotacji ludności tworzy specyficzną, niejednokrotnie familiarną, sąsiedzką atmosferę, której towarzyszy rozpoznawalność, wiedza o wzajemnych kłopotach i potrzebach ${ }^{18}$. Cechą charakterystyczną jest także swoista duma (zwłaszcza mieszkańców historycznej części Nowej Huty) wynikająca z miejsca zamieszkania. U starszej generacji jest ona wzmacniana przynależnością do tych, którzy to miejsce budowali ${ }^{19}$. W przypadku wielu nowohucian poczucie odrębności jest intensyfikowane przekonaniem o „zostawieniu (ich) samym sobie” przez władze miasta i pomijania dzielnicy ${ }^{20} \mathrm{w}$ podejmowanych decyzjach inwestycyjnych ${ }^{21}$. Czynniki te przyczyniły się do ukształtowania się wyrazistej tożsamości lokalnej²2 i specyficznego przywiązania do przestrzeni.

Moja stała obecność w tej okolicy sprawiła, że zwróciłam uwagę na obszar przylegający bezpośrednio do poszczególnych bloków, czyli zieleńce pomiędzy wejściami (klatkami), ale także tereny położone $\mathrm{z}$ drugiej strony (w stosunku do wejść) poszczególnych bloków. W moim najbliższym otoczeniu (bezpośrednim sąsiedztwie) miejsca te w mniejszym lub większym stopniu noszą ślady zagospodarowania i urządzenia niekiedy prawdziwie miniaturowych ogródków. Ich wielkość jest uzależniona od powierzchni gruntu, która przynależy do danej wspólnoty mieszkańców ${ }^{23}$. Niekiedy obszar ten jest

świadomie zaczęłam dostrzegać i dokumentować (w notatkach, zdjęciach) wszystko, co było związane z przedogródkami, a także sposobami zagospodarowania zieleńców w okolicy mojego zamieszkania. Obecność Uszatka często ułatwiała nawiązywanie rozmów z sąsiadami. Jednak zawsze w takich przypadkach występowałam jako właścicielka kota i mieszkanka. Bardziej systematyczne prace, w tym udział w zebraniach dotyczących rewitalizacji przestrzeni podwórek z udziałem mieszkańców, były realizowane późną jesienią 2018 roku i w styczniu-lutym 2019 roku. Prezentowane materiały są zatem wynikiem mojej stałej obecności na tym terenie i zaangażowania się w codzienne życie społeczności, której od pewnego momentu towarzyszyła intensywna obserwacja uczestnicząca.

${ }^{17}$ Najdłuższy staż zamieszkania moich rozmówców to 58 lat.

${ }^{18}$ Przejawiającą się np.w codziennej pomocy bliskim sąsiadom czy opieką nad dzieckiem (materiały autorki).

${ }^{19}$ Fakty te zostały także odnotowane w dokumentacji konserwatorskiej, w której czytamy „To specyficzna społeczność, ze swoją dumą, pamięcią historyczną i rzadkim przekonaniem wielu, że sami zbudowali swoje miasto" (Myczkowski et al. 2016, s. 12).

${ }^{20}$ Opinie takie wielokrotnie miałam możliwość słyszeć od mieszkańców Nowej Huty. Abstrahuję w tym miejscu od stanu faktycznego zainteresowania dzielnicą, które w ciągu wielu lat z pewnością było zmienne. W tym miejscu warto odnotować, że tegoroczne obchody 70-lecia Nowej Huty mogą stać się okazją do zwrócenia szczególnej uwagi na dzielnicę (zob. Kraków będzie świętowat w Nowej Hucie, 01.03.2019), w przeciwieństwie do obchodów sprzed dziesięciu lat, kiedy już w 2008 roku rozpoczęto dyskusje jaki jest sens świętowania 60 rocznicy powstania Nowej Huty (Radłowska, Kozik, 13.09.2019).

${ }^{21}$ Takie odczucia sprawiają, że pojawiają się pomysły oderwania Nowej Huty od Krakowa i utworzenia niezależnego miasta (zob. Nowa Huta wolnym miastem?, 10.01.2019; Nowa Huta miastem?, 10.01.2019).

${ }^{22}$ Zob. Gut 1993, s. 117-136.

${ }^{23}$ Termin wspólnota w artykule stosuję wyłącznie w znaczeniu administracyjno-prawnym, dotyczącym ogółu właścicieli, których lokale wchodzą w skład określonej nieruchomości (wspólnota mieszkaniowa/ wspólnota mieszkańców). 
tak mały, że zieleńce są organizowane tylko między wejściami do bloku. W innych przypadkach zaledwie małą część przynależnego terenu przekształcono w przydomowe ogródki, oddzielając je od reszty powierzchni (również zarządzanej przez daną wspólnotę) najczęściej żywopłotami. Zadaniem tych nasadzonych roślin tworzących ogrodzenia - jak później przekonałam się - było i jest utrudnienie wstępu potencjalnym intruzom.

Spacerując po tym terenie od paru już lat obserwuję zmiany związane $\mathrm{z}$ porami roku, odsłaniającymi różne oblicza przydomowych przestrzeni. Widzę - podobnie jak i oglądający przywołany na początku film - zieleń, kwitnące hortensje, róże, groszki, a także malwy, a wiosną przebiśniegi, krokusy polne fiołki i konwalie. Gdzieniegdzie jednak zawsze w pobliżu ogródków - dostrzegam także inne zaskakujące rośliny, jak np. kwitnące, a później owocujące poziomki. $Z$ drzew najpopularniejsze są lipy, które w porze kwitnienia wydzielają słodką woń unoszącą się - zwłaszcza wieczorną porą - nad tymi najstarszymi częściami Nowej Huty. Inne pory roku nie są już tak łaskawe dla tych sensualnych doznań. Zwłaszcza wczesna wiosna, która nie zdąży okryć się pierwszą zielenią i kwieciem, a także późna jesień, która już porzuciła barwny strój odsłaniają to, co wcześniej było skrywane w bujnej roślinności.

Szczególnie ważne dla moich spostrzeżeń było jednak lato i jesień 2018 roku. Właśnie w tym czasie nowohuckie bukszpany - podobnie jak i w innych częściach Krakowa - zostały całkowicie zniszczone przez tzw. ćmę bukszpanową (Cydalima perspectalis $)^{24}$. Spowodowało to akcję kontrolowanego administracyjnie wycinania i następnie w określony sposób utylizowania zaatakowanych krzewów. W ten sposób inwazja szkodnika odsłoniła wnętrza ogródków. Ich stan można określić jako różnorodny - od takich, w których widać codzienną troskę i pielęgnację zasadzonych roślin, aż po takie, których czasy świetności dawno przeszły, a świadczą o niej wciąż żyjące rozrosłe dzikie krzaki róż, bzu czy innych roślin ozdobnych. Jednak nie kondycja ogrodnicza tych przestrzeni była moim największym zadziwieniem. Stały się nim uwidocznione pozostałości po amatorsko stawianych ogrodzeniach, po drewnianych lub metalowych furtkach pierwotnie wmontowanych $\mathrm{w}$ roślinne ogrodzenia. Furtki te, czasem miniaturowych rozmiarów, niejednokrotnie były od góry zwieńczone - widocznym jeszcze teraz - drutem kolczastym, a czasem były jeszcze zamykane na kłódki, dziś już całkowicie zardzewiałe. Powtarzający się obraz, który jak pierwotnie sądziłam był czymś wyjątkowym, jednak obserwowanym na co dzień ${ }^{25} \mathrm{w}$ mojej wspólnocie, był dla mnie zaskoczeniem. Bo czym-

${ }^{24} \mathrm{O}$ ćmie bukszpanowej informowały m.in. Zarząd Zieleni Miejskiej w Krakowie (ZZM Kraków, 10.02.2019) i Polskie Stowarzyszenie Ochrony Roślin (Ćma atakuje, 10.02.2019), a także internetowe fora ogrodników np. Forum ogrodnicze, 10.02.2019, czy e-ogródek, 10.02.2019.

${ }^{25}$ Jeden ze środkowych ogródków, znajdujący się pomiędzy dwoma wejściami bloku, w którym mieszkam, jest rozdzielony poprzecznie posadzonym żywopłotem, co utworzyło de facto dwa ogródki. Dostęp do jednego $z$ nich dodatkowo jest utrudniony przez zamontowaną furtkę. Jest to stan zastany i sądząc po wielkości żywopłotu już z pewnymi tradycjami. Co warte zauważenia, w czasie kiedy wprowadzaliśmy się, była to drewniana furtka, której sztachety były pomalowane na niebieskozielony kolor, zamykana na 
że są owe pozostałości ogrodzeń, furtek zamykanych niegdyś na kłódki czy klucze, a dla większego utrudnienia dostępu przez potencjalnych intruzów, zaopatrywanych jeszcze w drut kolczasty. Zadawałam sobie pytanie, przed kim właściwie te ogródki były „bronione”? Starając się zrozumieć miejsce, w którym mieszkam, dociekałam kiedy one powstały, kto je zakładał i kto obecnie nimi się opiekuje, albo kto troskę o nie zarzucif i dlaczego? Wróćmy zatem do początków, tylko ogólnie tu zarysowanych, Nowej Huty ${ }^{26}$.

Początkowo Nowa Huta miała być samodzielnym miastem zbudowanym jako zaplecze mieszkaniowe dla przyszłych pracowników wznoszonego kombinatu metalurgicznego. Budowę pierwszych domów rozpoczęto w 1949 roku w gminie Mogiła. Były one zgodne z projektem architekta Franciszka Adamskiego ${ }^{27}$ i powstały we wschodniej części dzisiejszej Dzielnicy XVIII, tworząc osiedla Wandy28, Willowe i Na Skarpie. Projektanci Nowej Huty oparli się na koncepcji ,jednostki sąsiedzkiej”29, czyli samodzielnych układów osadniczych/osiedli liczących około 4-5 tysięcy ludzi. Poszczególne jednostki miały zapewniać wszystkie podstawowe potrzeby mieszkańców, stąd na ich terenie planowano i wznoszono obiekty użyteczności publicznej, takie jak sklepy, przedszkola, szkoły, ośrodki zdrowia, place zabaw ${ }^{30}$. Na osiedlu Willowym został utworzony pierwszy nowohucki rynek. Obecnie nosi on nazwę „Plac przy Poczcie”, nawiązującą do budynku poczty wzniesionego wzdłuż jednego z boków rynku. Wedle opinii Waldemara Komorowskiego, w budowie Nowej Huty można wydzielić trzy etapy. Pierwszy dotyczy pierwszych osiedli budowanych w latach $1949-1950^{31}$, drugi to reali-

kłódkę i od góry (ponieważ nie była zbyt wysoka) zabezpieczona drutem kolczastym. Trzy lata temu stara furtka została zdemontowana, a na jej miejsce wstawioną nową, metalową, wyższą, która nie ma już drutu kolczastego, a jedynie spiczaste i dosyć ostro zakończone pręty. Nowa furtka jest zamykana na klucz, który posiada jedynie osoba troszcząca się (bardzo starannie) o tę część przydomowego ogródka (materiały własne autorki).

${ }^{26}$ Nowa Huta doczekała się licznych opracowań naukowych, ukazujących problematykę społeczną, demograficzną, kulturową, urbanizacyjną, ochrony konserwatorskiej - by wymienić tylko te pola, które są istotne z punktu widzenia zagadnień poruszanych w niniejszym artykule. Wydana sześć lat temu praca Moniki Golonki-Czajkowskiej zawiera najpełniejsze zestawienie literatury poświęconej tej dzielnicy Krakowa (zob. Golonka-Czajkowska 2013), nowsze opracowania powstające w związku z planem utworzenia Parku Kulturowego Nowa Huta cytuję w tym artykule.

${ }^{27}$ Karpińska 2018, s. 24-29; Pierwsze osiedla w Nowej Hucie, 10.02.2019.

${ }^{28}$ Pierwszy blok Nowej Huty znajduje się na os. Wandy, obecnie nosi numer 14. Na frontowej fasadzie bloku znajduje się tablica upamiętniająca ten fakt.

${ }^{29}$ Koncepcja tzw. jednostki sąsiedzkiej (neighbourhood unite concept) została zastosowana „po raz pierwszy w latach dwudziestych XX wieku w Nowym Jorku przez jej twórcę Clarence'a Perry'ego, zakładającą samowystarczalność zespołu mieszkaniowego w zakresie kompleksowej infrastruktury usługowej (opartej o moduł pojemności szkoły). Zasada jednostki sąsiedzkiej przejęta została już w okresie międzywojennym przez ukierunkowaną społecznie polską myśl urbanistyczną (Warszawska Spółdzielnia Mieszkaniowa)"; Beiersdorf, Komorowski 2010, s. 18.

${ }^{30}$ Magiczny Kraków, 10.02.2019.

31 „Powstawały w nich jedno- i dwupiętrowe budynki z wysokimi dachami, w układach rozproszonych, rytmicznie uszeregowanych. Kameralne zespoły, otoczone obszernymi terenami zielonymi, nawiązują do 
zacje z lat 1950-56 32 . Ostatni z wyróżnianych etapów przypada na lata po roku $1956^{33}$. Komorowski zaznacza jednak również, że:

We wszystkich trzech okresach stosowano nowoczesną metodę urbanistyczną, kryjąc ją z konieczności za przeciwnymi jej sloganami ideologicznymi, a także przez krótki czas pod historycznym kostiumem formalnym ${ }^{34}$.

Realizacje budowlane wznoszone w końcu lat 70. XX wieku i w latach późniejszych są postrzegane przez architektów i konserwatorów zabytków jako dysonans ${ }^{35}$, powodujący „etapową deprecjację neobarokowej kompozycji centrum miasta” ${ }^{\text {36 }}$.

W projektowanej przestrzeni wytyczono ciągi komunikacyjne i pozostawiano stosunkowo obszerne przestrzenie na planowane zieleńce wzdłuż traktów pieszych i samochodowych ${ }^{37}$ oraz wokół wznoszonych bloków ${ }^{38}$. Zieleń reprezentacyjnych placów, a także wzdłuż alei wyznaczających osie widokowe Nowej Huty była nasadzana zgodnie z planami architektów. Obszary bezpośrednio przylegające do poszczególnych bloków

tradycji modernistycznych osiedli pracowniczych miast przemysłowych Polski międzywojennej, dopatrzyć się też w nich można wpływów anglosaskiej idei miast-ogrodów i amerykańskich oraz niemieckich kolonii pracowniczych z przełomu XIX i XX w., a także z okresu międzywojennego (m.in. we Wrocławiu)" (Komorowski 2017, s. 153).

32 Jak pisze W. Komorowski był to okres arbitralnie narzuconej i lansowanej doktryny realizmu socjalistycznego, która „(...) wymusiła porzucenie koncepcji miasta-ogrodu. Zmieniły się też priorytety w zakresie budownictwa mieszkaniowego, dążono do zagęszczenia zabudowy z powodu modyfikacji programu nowego miasta, które miało obsługiwać większą niż pierwotnie planowano hutę. Plac Centralny i przylegle osiedla zrealizowano w 1. 1952-1956. Zespół Tadeusza Ptaszyckiego stworzył dzieło spełniające wymogi doktryny, według której centrum socjalistycznego miasta miało stanowić oprawę manifestacji poparcia ludu dla władzy. Uczyniono to jednak środkami zgoła niespodziewanymi, sięgając nie do modelowych przykładów radzieckich, ale wprost do wzorów zachodnioeuropejskich” (Komorowski 2017, s. 154).

33 „Demonstracyjnie zerwano z zasadą ściśle symetrycznego kształtowania założeń urbanistycznych oraz przestrzegania harmonii elementów horyzontalnych i wertykalnych (...) już w 1956 r. powstały projekty, które zerwały z zabudową obrzeżną, z zamkniętymi wnętrzami urbanistycznymi, na korzyść założeń swobodnych, kształtowanych według ówczesnych światowych tendencji. Wciąż jednak wpisywały się w urbanistyczny ruszt miasta z pierwszej połowy lat pięćdziesiątych. Architektura też była już «nowa»” (Komorowski 2017, s. 154-155).

${ }^{34}$ Komorowski 2017, s. 155.

${ }^{35}$ Uwaga ta dotyczy obszaru, na którym planowane jest utworzenia Parku Kulturowego Nowa Huta.

${ }^{36}$ Komorowski 2017, s. 156.

${ }^{37}$ Wewnątrz poszczególnych osiedli ciągi komunikacyjne, przeznaczone dla pieszych i wówczas nielicznych aut, były wspólne. Projektanci nie przewidzieli, że w przyszłości nastąpi tak znaczny wzrost liczby samochodów. W związku z tym nie zaprojektowano wystarczająco przestronnych ulic z wydzieloną częścią dla pieszych, a także miejscami parkingowymi. Jest to jeden $z$ ważniejszych problemów, bardzo trudnych do rozwiązania zwłaszcza wobec objęcia tego obszaru ochroną konserwatorską (zob. Myczkowski, Siwek 2017, s. 122; Komorowski 2017, s. 161).

${ }^{38}$ Poźniejsze inwestycje budowlane przewidywały już większe zagęszczenie wznoszonych budynków mieszkalnych (Komorowski 2017, s. 154). 
były jednak w większości przypadków organizowane przez mieszkańców zasiedlających dopiero co wzniesione domy, którzy w znacznej mierze byli także ich budowniczymi. Często pochodzili oni z biednych wiejskich rodzin, a duża inwestycja przemysłowa budziła w nich nadzieję na lepszą przyszłość.

Obraz terenu, który zasiedlano był jednak odmienny od tego, który widzimy współcześnie. Stare zdjęcia Nowej Huty ${ }^{39}$ ukazują nowo wzniesioną, a czasem jeszcze wznoszoną, architekturę, którą otaczają pustki ${ }^{40}$. Brak jest, widocznej dzisiaj, zieleni drzew, krzewów, kwiatów, ogródków. To wszystko dopiero miało powstać. Jak już wcześniej sygnalizowałam, nasadzenia zgodne z planami architektów i architektów zieleni były realizowane w przestrzeniach reprezentacyjnych, takich jak Plac Centralny, Aleja Róż, czy dzisiejsza Aleja Solidarności. Fakty te znalazły także odzwierciedlenie w trakcie moich badań terenowych.

Pracownicy Zarządu Zieleni Miejskiej w Krakowie, koordynujący projekt miejski „Spotkajmy się na podwórku”41, w trakcie spotkania z mieszkańcami przyznali, że większość współcześnie oglądanych aranżacji wewnątrz osiedli jest wynikiem spontanicznych działań miejscowej ludności i jej wieloletniej troski o zamieszkiwaną przestrzeń ${ }^{42}$. To ich preferencje estetyczne, najczęściej nie kształtowane żadnymi formami edukacji, lecz wyniesione $z$ domu, stały się podstawą dla aranżowania najbliższego otoczenia, przede wszystkim poprzez wybór roślin sadzonych wokół domów. Tak zaczęły powstawać wspomniane przydomowe ogródki, nieuchronnie przywodzące na myśl ich wiejskie odpowiedniki. Ich zakładanie niewątpliwie jest wyrazem tęsknoty za tym, co pozostawiono wraz $z$ opuszczeniem rodzinnego domu ${ }^{43}$. Z przestrzeni otaczających bloki wydzielano małe działki, którymi następnie opiekowały się poszczególne osoby. Były one zagospodarowywane przede wszystkim jako kwiatowe powierzchnie. W przypadku większych parcel sadzono także kwitnące krzewy, takie jak bez czy tarnina. Od innych były one oddzielane różnego typu ogrodzeniami. Najczęściej były to roślinne płoty, kształtowane z ligustry (Ligustrum vulgare L.) i bukszpanu (Buxus L.) lub innych roślin nadających się do tego celu. Niekiedy stawiano również rzeczywiste płoty z siatki.

\footnotetext{
${ }^{39}$ Nowa Huta na starych zdjęciach, 15.02.2019.

${ }^{40}$ Mądrala, Piła 2014. Ponadto należy przypomnieć, że „w latach 1940-1945 na terenie, gdzie dzisiaj znajduje się szpital i pobliskie os. Na Skarpie oraz os. Młodości, funkcjonował obóz pracy przymusowej Baulager 15/XIV, w którym od 1941 r. Niemcy przetrzymywali radzieckich jeńców wojennych" (Wiśniewski 2018, s. 37).

${ }^{41}$ Jednym z celów tego projektu jest rewaloryzacja wnętrz ośmiu wybranych podwórek znajdujących się na terenie starej Nowej Huty (Spotkajmy się na podwórku, 10.01.2019).

${ }^{42}$ Materiały własne autorki, a także: Mądrala, Piła 2014.

${ }^{43}$ Alternatywą dla zakładanych ogródków przydomowych stały się Rodzinne Ogrody Działkowe. To właśnie tutaj pełniej mogły być zaspakajane dążenia do posiadania „własnej” działki i sposobów jej zagospodarowania. Według informacji UM Kraków najwięcej krakowskich ROD-ów znajduje się właśnie na terenie Nowej Huty (Przysztość ROD, 26.02.2019).
} 
W większości znanych mi przypadków ogródki zwyczajowo „przynależały” ${ }^{44}$ do osób mieszkających na parterze. I najczęściej tylko one miały pełny dostęp do tej przestrzeni. Zdarzało się jednak również, że pielęgnacją zajmował się ktoś z wyższych kondygnacji, jednak zawsze za zgodą mieszkańca parteru ${ }^{45}$. Przyjęło się, że w przypadku zmiany lokatora, opiekę nad ogródkiem przejmowały osoby, które wprowadzały się. Zwyczaj ten obowiązuje do dzisiaj, czego doświadczyłam wybierając lokal na parterze bloku. W trakcie prowadzonych rozmów wstępnych, dotyczących sprzedaży/kupna z właścicielami wybranego przez nas mieszkania nasza poprzedniczka, nieśmiało zaznaczyła, że ,jest jeszcze ogródek, nad którym opieka tradycyjnie przynależy do tego mieszkania”. Wyraźnie było widać zakłopotanie mojej rozmówczyni. W dalszych słowach wyjaśniła, że nie wszyscy są zadowoleni z „tego spadku tradycji”" ${ }^{46}$, a przechodzący obowiązek opieki na nowych lokatorów był postrzegany przez potencjalnych kupców jako obniżenie atrakcyjności mieszkania.

Poszczególne ogródki, nawet w obrębie jednego bloku, nie były - i także współcześnie najczęściej nie są - takie same. Każdy opiekujący się daną przestrzenią sam decydował o tym, co zostanie zasadzone.

Kreowanie ogródków poprzez sadzenie określonej roślinności, ale także wyraźne ich odgraniczanie od innych, jest nie tylko próbą stworzenia własnego miejsca w obcym świecie. Wyznaczanie granic poprzez hodowanie i wieloletnią troskę o żywopłoty limitujące przestrzeń jest wyznaczaniem granic własnego świata ${ }^{47}$. Świata, do którego nikt inny nie powinien mieć wstępu. Jest chroniony nie tylko roślinnymi ogrodzeniami, ale także stawianymi furtkami zamykanymi na klucz/kłódkę. Potrzeba wydzielania $\mathrm{w}$ amorficznej przestrzeni obszarów znanych, bezpiecznych, swoich (Orbis Interior), od przestrzeni nieznanych, niebezpiecznych, obcych (Orbis Exterior) poprzez wyznaczenie granic i oddzielenie tych dwóch kategorii światów jest immanentną potrzebą człowieka ${ }^{48}$.

Czas zakładania ogródków to moment stabilizacji, dającej podstawy do „układania sobie życia” przez ówczesnych nowohucian - zawierania małżeństw, zakładania rodzin, wprowadzania się do własnych mieszkań. Jak zaznacza Monika Golonka-Czajkowska,

${ }^{44}$ Oczywiście działania, skutkiem których było powstanie takich obszarów, nie miały jakiejkolwiek podstawy prawnej, ani w czasie, kiedy je tworzono, ani współcześnie. Grunt należący do danej wspólnoty jest jej wspólnym dobrem, do którego każdy mieszkaniec powinien mieć pełny dostęp i wpływ na to, jak jest zagospodarowywany.

${ }^{45}$ Zdarzało się tak, gdy ktoś, np. ze względów zdrowotnych, nie mógł już opiekować się ogródkiem.

${ }^{46}$ Materiały własne autorki.

${ }^{47}$ Także ten element został odnotowany w opracowaniach konserwatorów: „W przestrzeniach śródblokowych daje się zaobserwować proces podziału przestrzeni. Elementami dzielącymi są głównie budynki garaży, ogrodzenia i zieleń” (Myczkowski et al. 2016, s. 11). Przywołany dokument w ogólnych zaleceniach informuje o wprowadzanym zakazie limitowania przestrzeni przede wszystkim wokół bloków mieszkalnych (Myczkowski et al. 2016, s. 17).

${ }^{48}$ Eliade 1999, s. 50. 
od połowy lat 50, XX wieku wraz z budową kolejnych osiedli i uruchomieniem produkcji w kombinacie normalizuje się sytuacja społeczna dzielnicy ${ }^{49}$. Dotychczasowi osadnicy przekształcają się w mieszkańców, wchodzących w nowe role społeczne ${ }^{50}$, a to, co szczególnie dla mnie ważne - organizujących przestrzeń swojego życia. Nie tylko tę najbliższą, domową, którą najczęściej musieli dzielić jeszcze przez wiele lat z innymi rodzinami ${ }^{51}$, ale także tę niezagospodarowaną, a otaczającą ich blok. Możliwość kształtowania przestrzeni, poprzez wydzielanie $z$ niej obszarów swoich, przez siebie organizowanych, tworzonych, jest jednym z najsilniejszych czynników wpływających na identyfikację z tym wyodrębnionym i kreowanym miejscem. Za Wallisem przypomnę, że

kształtowanie przestrzeni społecznej jest procesem stałym, w którym trwa nieustanne jej dostosowywanie do społecznych potrzeb i dostosowywanie się społeczeństwa do istniejącej przestrzeni. Społeczeństwo kształtuje zatem przestrzeń bądź bezpośrednio - kształtując ją, bądź pośrednio - przystosowując się do niej. Statystycznej jednostce bezpośrednie kształtowanie przestrzeni dostępne jest w skromnym zakresie - we własnym mieszkaniu, a najwyżej w jego najbliższym otoczeniu ${ }^{52}$.

Zakładanie i pielęgnację ogródków należy rozpatrywać w odniesieniu do co najmniej dwóch okresów. Pierwszy dotyczy czasu organizowania tych najbliższych przydomowych przestrzeni. Na tym etapie podejmowane działania są przejawem dążenia do ukształtowania zasiedlanego terenu w taki sposób, by chociaż w jakiejś mierze uczynić go bardziej swojskim, podobnym do tego znanego z rodzinnych stron. Należy je rozpatrywać jako próbę oswojenia obcej przestrzeni, stworzenia nie tylko „domu” w ramach przydziałowego mieszkania, ale także zadomowienia otoczenia bezpośrednio przylegającego do zamieszkiwanego bloku. Jest tworzeniem miejsca przez ludzi, którzy zaczęli kreować swój nowy świat, a jego częścią były przydomowe ogródki. W wyborze roślin preferowano te znane $z$ rodzinnych stron, tak jak wspominane na początku lipy, ale także brzozy, świerki, modrzewie, tarniny, bzy. Powszechne były bukszpany. Wśród roślin ogrodowych spotykanych do dzisiaj w nowohuckich ogródkach są np. malwy czy pnące róże, pojawiają się też tulipany i hortensje. Trzeba jednak przyznać, że współcześnie towarzyszą im zazwyczaj rośliny o bardziej egzotycznym rodowodzie, takie jak różnego rodzaju iglaki typu tuje. Pojawienie się tych roślin wyznacza drugi etap, czasy, kiedy troska nad ogródkami przeszła w ręce nowych mieszkańców - czasem spadkobierców założycieli ogródków, a czasem osób niezwiązanych z tymi miejscami. Wtedy to właśnie

\footnotetext{
${ }^{49}$ Golonka-Czajkowska 2013, s. 321.

${ }^{50}$ Golonka-Czajkowska 2013, s. 322.

${ }^{51} \mathrm{~W}$ rzeczywistości powszechną praktyką było zamieszkiwanie w jednym mieszkaniu dwóch, trzech rodzin. $Z$ reguły jeden pokój był przeznaczony dla jednej rodziny. Pozostałe pomieszczenia - kuchnia, łazienka i toaleta - były użytkowane wspólnie (materiały autorki; Golonka-Czajkowska 2013, s. 322).

52 Wallis 1990, s. 25.
} 
ogródki zaczynają się różnicować. Niektóre podupadają, inne zyskują oblicze przybrane nasadzeniami „nowoczesnych roślin” ${ }^{3}$. Ten drugi etap wciąż trwa.

Obserwując ogródki na tych najstarszych osiedlach nowohuckich, nie sposób nie zauważyć pewnych różnic w obrębie poszczególnych osiedli. Szczególnie wyróżniają się zieleńce wokół bloków na osiedlu Młodości. Jest to najmniejsze osiedle w Nowej Hucie, które tworzą domy pierwotnie pełniące funkcję hoteli robotniczych. Dopiero w latach 90. XX wieku zostały one przekształcone na bloki mieszkalne, w większości przypadków z mieszkaniami dla pracowników kombinatu. Na przełomie XX i XXI wieku osoby, które tu zamieszkały ogrodziły metalowymi płotami obszary należące do poszczególnych wspólnot, a zieleńce urządzono zgodnie ze współczesnymi trendami ${ }^{54}$. Ich cechą charakterystyczną jest jednolity sposób aranżowania zielonej przestrzeni, a więc inna - w porównaniu do opisanych wcześniej ogródków - organizacja terenu wokół budynku. W tych przypadkach widać współpracę całej wspólnoty w wypracowaniu jednolitego planu (te same rośliny nasadzone w pewnym ładzie kompozycyjnym) dla zarządzanego obszaru. Warto podkreślić, że jest on wprawdzie dostępny dla wszystkich członków danej wspólnoty (i ewentualnie ich gości), jednak jest zamknięty dla innych, nawet bliskich sąsiadów ${ }^{55}$.

Czas zasiedlania osiedla Młodości i reorganizacji jego przestrzeni, poprzez jej limitowanie, to okres, kiedy i na sąsiednich osiedlach można zauważyć zachodzące zmiany i nasadzenia nowych roślin. Odmienna - w porównaniu do okolicznych osiedli - sytuacja związana ze stałym zasiedlaniem mieszkań na osiedlu Młodości przyczyniła się do odróżnialnego sposobu organizowania przestrzeni przez jego mieszkańców. Jest on wyraźnie inspirowany powstającymi już w końcu XX wieku grodzonymi osiedlami, z bramami wjazdowymi i jednolicie projektowanymi terenami zielonymi.

Pewną odmienność można także zaobserwować na osiedlu Willowym. Na tym obszarze tylko niekiedy można dostrzec ogródki z wyraźnymi granicami wyznaczanymi

${ }^{53}$ Mam na myśli przede wszystkim różnego rodzaju iglaki o egzotycznym pochodzeniu, które stały się także elementem aranżacji przestrzeni wokół domów jednorodzinnych zarówno na obrzeżach miast, jak i przy domach na wsi. Na szczególną uwagę zasługuje współczesne zagospodarowanie obszaru wokół domów wiejskich, który zazwyczaj jest wybrukowany kostką, natomiast nasadzenia drzew i krzewów iglastych tworzą szpalery i ciągi komunikacyjne w obrębie posiadłości. Dawne ogródki zostały zastąpione klombami. Powszechnie sadzone tuje - często bardzo gęsto - tworzą naturalną zasłonę, izolującą od sąsiadów. Rzadko można spotkać dawne ogródki z kwiatami, ziołami. Współczesny typ aranżacji przestrzeni wokół wiejskich domów, jest w pewnym stopniu przejawem mody, jednak przede wszystkim zmieniającego się stylu życia na wsi (materiały autorki).

${ }^{54}$ Ustawiono także szlaban sterowany elektronicznie, uniemożliwiający wjazd do osiedla nieupoważnionym osobom. Na terenie jednej ze wspólnot zorganizowano maleńki ogródek jordanowski przeznaczony tylko dla dzieci z tej wspólnoty.

${ }^{55}$ Wprowadzenie do przestrzeni tego osiedla ogrodzeń zostało odnotowane w dokumentacji konserwatorskiej, w której czytamy: „dziś blokami rządzą wspólnoty, które poodgradzały swe domy parkanami, demolując wspólną przestrzeń. Pod tym względem to najsmutniejsze z nowohuckich osiedli”, Charakterystyka poszczególnych osiedli..., 20.01.2019. 
przy pomocy wyhodowanych, naturalnych, roślinnych ogrodzeń, które organizowano bezpośrednio pod oknami mieszkań. Zazwyczaj są to obszerne zieleńce $\mathrm{z}$ nasadzoną różnorodną roślinnością. Żywopłoty pojawiają się tutaj najczęściej dopiero wzdłuż chodników i ulic. Warto w tym miejscu przypomnieć, że domy na osiedlu Willowym były najczęściej zasiedlane przez Romów ${ }^{56}$, dla których zakładanie i codzienna pielęgnacja ogródków nie miała uzasadnienia zwyczajem kulturowym.

Wciąż najwięcej ogródków, przybierających różne konfiguracje wokół domów, a także najbardziej zróżnicowanych pod względem nasadzonej roślinności i zadbania można zaobserwować wewnątrz osiedla $\mathrm{Na}$ Skarpie.

Obserwacje, a także rozmowy, które przeprowadziłam wskazują na pewną prawidłowość i korelację między kondycją omawianych przydomowych przestrzeni i stosunkiem do nich mieszkańców. Dobra forma ogrodnicza, a także różnorodność nasadzonej roślinności i zadbanie, wynikają najczęściej z indywidualnych starań konkretnych osób, ich pasji ukierunkowanej na kultywowany kawałek ziemi. W tych przypadkach wsparcie ze strony wspólnoty nie tylko nie jest oczekiwane, ale nawet byłoby postrzegane jako „wtrącanie się w nie swoje sprawy" ${ }^{57}$. W większości przypadków opiekunami są jednak „ogrodnicy z przypadku”, którzy pielęgnują powierzoną im przestrzeń - na mocy lokalnego zwyczaju. Brak czasu, a niekiedy i zamiłowania, a także brak wsparcia ze strony innych członków wspólnoty powoduje minimalizację koniecznych działań i wybór roślin mało kłopotliwych. Tę grupę osób cechuje największa otwartość na ewentualne zmiany w sposobie realizacji troski o przydomowe przestrzenie. Dobrze ukazuje to wypowiedź jednego z moich rozmówców:

„Nie chcemy by rosły tu chwasty i my zakrzaczyliśmy ogródek (zasadzono krzewy-E.B.K.), bo nie mamy na niego czasu. Byłoby ładniej, a dla nas wygodniej, gdyby robić to całościowo; dla całej wspólnoty" ${ }^{58}$.

Zaniechanie jakiejkolwiek troski ogrodniczej jest zazwyczaj związane z niemożnością prowadzenia dalszych prac przez osoby, które do tej pory to robiły i niechęcią poszczególnych osób, jak i całej wspólnoty, do uporządkowania dawnych przestrzeni ogródkowych. Ta ostatnia postawa jest warunkowana - w świetle posiadanych materiałów - dwoma czynnikami. Pierwszy to niechęć do podejmowania przez wspólnoty decyzji, których konsekwencją byłoby podniesienie kosztów utrzymania nieruchomości, wynikające $z$ potrzeby zatrudnienia firmy do pielęgnacji zieleni. W takich przypadkach

\footnotetext{
${ }^{56} \mathrm{~W}$ późniejszych latach poszczególne rodziny wyprowadzały się do innych dzielnic Krakowa, jednakże do dzisiaj właśnie na tym osiedlu można spotkać potomków pierwszych romskich osadników (materiały autorki).

${ }^{57}$ Sytuacje takie miałam możliwość obserwować w dwóch wspólnotach (materiały autorki).

${ }^{58}$ Materiały autorki.
} 
zdecydowanie łatwiej dla większości członków poszczególnych wspólnot, pozostawić problem - dosłownie i w przenośni - „odłogiem” ${ }^{\text {99 }}$. Drugim czynnikiem jest bardzo silny związek uczuciowy, jaki wytworzył się pomiędzy osobami pielęgnującymi ogródki i doglądaną przez nich przestrzenią. Dotyczy to zarówno sytuacji, kiedy obserwowałam zaangażowaną troskę o przydomowy ogródek, jak i w przypadku całkowitego jej zaniechania. W pierwszym przypadku nawet przebiegnięcie kota, pojawienie się niedopałków papierosów, czy inne ślady obecności nieupoważnionego człowieka były powodem awantur, w które angażowani byli także inni członkowie wspólnoty ${ }^{60}$. Spacerując ze swoim czworonogiem, miałam możliwość obserwować emocjonalne reakcje, także wtedy, gdy nieintencjonalnie naruszałam przestrzeń niezauważonego ogródka. Niezauważonego, ponieważ stopień jego zaniedbania kojarzył się raczej z porzuconym, bezpańskim obszarem o „zatartych” śladach dawnych granic, o którym niegdysiejsi jego gospodarze już dawno zapomnieli. Jednak naruszenie tej, wydawałoby się, niczyjej przestrzeni, wywoływało niekiedy bardzo gwałtowną reakcję ze strony osób, które wprawdzie - sądząc po kondycji ogródka - dawno zarzuciły o niego troskę, ale nie utraciły względem niego poczucia własności ${ }^{61}$. Dążenie do unikania konfliktów wewnątrz wspólnoty sprzyja również niechęci do ingerowania w sytuacje, które zyskały status prawa zwyczajowego ${ }^{62}$.

Emocjonalne reakcje na naruszenie granic ogródka wskazują nie tylko na mocne zadomowienie $\mathrm{w}$ przestrzeni, identyfikowanie się z nią. W tych przypadkach trafniej mówić o głęboko emocjonalnym osadzeniu w danym miejscu, o zakorzenieniu. Buczyńska-Garewicz zwraca uwagę na różnice znaczeń terminów zamieszkiwanie i zakorzenienie. Wyjaśnia „Zamieszkiwaniem nazywamy (...) rozumiejący sposób przebywania człowieka w miejscu" i zaznacza, że pojęcie to cechuje moment wolności, właściwy sposobowi bycia przez zamieszkiwanie ${ }^{63}$. Natomiast

${ }^{59}$ Jedna ze wspólnot mieszkańców, która zlikwidowała całkowicie ogródki przed swoim blokiem, skutkiem czego rosła tam mocno zachwaszczona trawa, prowadzi obecnie wewnętrzną dyskusję na temat sposobu zagospodarowania tych przestrzeni. W innej wspólnocie dyskusja na temat ujednolicenia wszystkich ogródków zakończyła się niepowodzeniem. Głównym uzasadnieniem odrzucenia tych propozycji były koszty, które należałoby uwzględnić w utrzymaniu nieruchomości, co wiązałoby się z podniesieniem czynszu dla mieszkańców. W obydwu tych wspólnotach w trakcie dyskusji zwracano uwagę na fakt, że jest to teren gminy Kraków, a nie obszar należący do wspólnoty (materiały autorki).

${ }^{60}$ Materiały autorki.

${ }^{61}$ Jest to nie tylko moje doświadczenie, ale także innych osób, którym zdarzyło się naruszyć - nawet niechcący i bez złych zamiarów - przestrzeń przydomowego ogródka. O perypetiach związanych z naruszeniem granic ogródków opowiadali moi rozmówcy, którzy wspominając czasy dzieciństwa, opisywali swoje ówczesne kłopoty, gdy np. piłka w trakcie zabawy wpadła do ogródka sąsiada (materiały autorki).

${ }^{62}$ Wątek konfliktów powstających wokół ogródków zostanie szerzej rozwinięty w osobnym opracowaniu.

${ }^{63}$ Buczyńska-Garewicz 2006, s. 42. 
Zakorzenienie tym się różni od zamieszkiwania, że brak mu charakteryzującej to ostatnie samodeterminacji i towarzyszącej jej niezbywalnie otwartości na inność i nowość (...)

Takie też sensy niesie zakorzenienie z przysługującym mu nieodwołalnie brakiem wyboru i możliwości ruchu. Korzenie z istoty swej są roślinne (rzeczowe), a nie rozumiejące, co musi być istotą zamieszkiwania. Zakorzenienie to umacnianie swej pozycji w ziemi za pomocą korzeni, przenośnie zaś to tyle, co utrwalanie czegoś głęboko w sercu lub w duszy ${ }^{64}$.

Niejednokrotnie można dostrzec zaniechanie jakiejkolwiek troski o te wydzielone niegdyś miejsca. Zostawienie ich samym sobie, brak zainteresowania ze strony innych członków danej wspólnoty, wskazuje, że dla wielu osób taka forma dbałości o najbliższą przydomową przestrzeń nie jest ważna. Świadczy również o braku odczuwanego związku z zamieszkiwanym terenem i unikaniem dodatkowych kosztów z tym związanych.

Odmienną postawę reprezentują osoby, dla których pielęgnacja przydomowych ogródków, jest dostosowaniem się do lokalnych zwyczajów, jednak otwartym na potencjalne zmiany w sposobie gospodarowania przestrzenią administrowaną przez wspólnotę.

Zmieniające się przestrzenie wokół najstarszych nowohuckich bloków odzwierciedlają zmiany zachodzące w zamieszkującej je społeczności. Ukazują proces starzenia się tych, którzy ogródki zakładali i zamierania codziennej o nie troski. Młodsze pokolenie niekiedy kontynuuje dzieło swoich poprzedników i nadal dba o „odziedziczone” obszary. Włącza jednak do uprawianych roślin nowe, wcześniej nieznane lub mało popularne w przeszłości gatunki. Nierzadko rezygnuje z czasochłonnej uprawy roślin jednorocznych, decydując się na równo przystrzyżony trawnik przyozdobiony krzakiem hortensji lub iglakami. Niekiedy - jak na osiedlu Młodości - na wzór wznoszonych osiedli grodzonych, dąży do zmiany otaczającej je przestrzeni i wyraźnego odgrodzenia swojej wspólnoty od innych. Ogródki istnieją w różnej kondycji; nawet jeśli robią wrażenie zaniedbanych, porzuconych, to często są one dla kogoś wciąż ważnym miejscem. Jego naruszenie przez kogokolwiek, potencjalnego „obcego”, czasem nawet bliskiego sąsiada, może wywołać zupełnie nieoczekiwaną reakcję.

Ogródki i całość życia indywidualnego i społecznego, jaka była/jest z nimi związana to element codzienności, codziennego krzątania się po tym rozszerzonym domostwie, obejmującym nie tylko mieszkanie, ale także przestrzeń znajdującą się bezpośrednio pod jego oknami. Czas ich zakładania i świetności, to także okres szczytu możliwości życiowych ich opiekunów. Dla niektórych mieszkańców ogródki stały się centrum ich życia - jedyną rozrywką, przyjemnością, powodem do dumy. Dla wielu to także wspomnienie ich przeszłej codzienności, w której było miejsce zarówno na dobre relacje $\mathrm{z}$ sąsiadami, jak i czasem konflikty związane $\mathrm{z}$ naruszaniem granic tego, co postrzegano jako własne.

${ }^{64}$ Buczyńska-Garewicz 2006, s. 42. 
Uwagi, którymi podzieliłam się w tym artykule są wynikiem refleksji, wywołanych filmem Nowohuckie podwórka i doświadczenia, jakim było zamieszkanie na osiedlu, które od lat już zostało zadomowione przez poprzednich i obecnych mieszkańców. Wypełnili oni zamieszkiwaną przestrzeń znaczeniami i sieciami powiązań, niekiedy krzyżującymi się, a niekiedy wykluczającymi (jak w przypadku analizowanych ogródków). Moje początki zadomawiania się na tym terenie przypominają ogląd tych miejsc przez filmową przewodniczkę. Zamieszkanie, a w moim przypadku także spacerowanie z Uszatkiem, nieuchronnie prowadziło do wchodzenia w relacje z innymi ludźmi - także do odkrywania ogródków. Dopiero ten etap ukazuje to, co jest pozornie niewidoczne. Pozornie, ponieważ to poznanie prowadzi do świadomego odkrycia i umiejętności czytania znaczeń różnych elementów przestrzeni. Prowadzi do dostrzeżenia różnic, także granic w terenie, który wydawał się homogeniczny.

\section{Bibliografia}

Augé M. 2010, Nie-miejsca. Wprowadzenie do antropologii hipernowoczesności, Wydawnictwo Naukowe PWN, Warszawa.

Beiersdorf Z., Komorowski W. 2010, Nowa Huta lat pięćdziesiatych. Dziedzictwo - zagrożenia i perspektywy [w:] Bogusław Szmygin, Jörg Haspel (red.), Zabytki drugiej potowy XX wieku-waloryzacja, ochrona, konserwacja / Das Erbe Der Nachkriegszeit Erhalten und ErneuernDenkmale Der Moderne und Gegenmoderne / Architecture of The Second Half of The 20th Century - Studies and Protection, ICOMOS Polska / ICOMOS Deutschland, Warszawa-Berlin, s. 17-28.

Bielecka-Prus J. 2011, Etic i emic (Etic and emic), [w:] K.T. Konecki, P. Chomczyński (red.), Stownik socjologii jakościowej, Wydawnictwo Difin, Warszawa, s. 67-69.

Buczyńska-Garewicz 2006, Miejsca, strony, okolice. Przyczynek do fenomenologii przestrzeni, UNIVERSITAS, Kraków.

Burszta W. 1987, Emic/Etic, [w:] Z. Staszczak (red.), Stownik etnologiczny terminy ogólne, PWN, Warszawa-Poznań, s. 74-75.

Eliade M. 1999, Sacrum i profanum. O istocie religijności, Wydawnictwo KR, Warszawa.

Golonka-Czajkowska M.2013, Nowe miasto, nowych ludzi. Mitologie nowohuckie, Seria Anthropos, Wydawnictwo UJ, Kraków.

Gut D. 1993, Nowa Huta w świadomości jej mieszkańców, [w:] J. Bujak, A. Zambrzycka-Kunachowicz, R. Godula (red.), Kraków - przestrzenie kulturowe, Wydawnictwo Katedry Etnologii UJ i Wydawnictwo Platan, Kraków, s. 117-136.

Karpińska M. 2018, Sektor A - poczatek miasta, [w:] J. Klaś (red.) Nowa Huta, Architektoniczny Portret Miasta drugiej potowy XX wieku, Wyd. Ośrodka Kultury im C.K. Norwida Instytucja Kultury Miasta Krakowa, Kraków, s. 24-31. 
Komorowski W. 2017, Ochrona dziedzictwa urbanistyki i architektury Norwej Huty z lat 1949-1959 / Heritage conservation for urban planning and architecture of Nowa Huta of the years 19491959, "Wiadomości Konserwatorskie" / "Journal of Heritage Conservation", nr 49/2017, s. 153-162.

Mądrala N, Piła K. 2014, Urbanistyka Nowej Huty - wady i zalety, http://urbnews.pl/urbanistyka-nowej-huty-wady-zalety/, dostęp 31.01.2019.

Myczkowski Z., Chajdas K., Forczyk-Brataniec U., Latusek K., Marcinek R., Nosalska P., Rymsza-Mazur W., Siwek A., Wielgus K. 2016, Plan ochrony Parku Kulturowego Nowa Huta, Etap II (2016), [w:] Tom III Synteza planu ocbrony Parku Kulturowego Nowa Huta (I-LX 2016), Kraków, https://www.bip.krakow.pl/zalaczniki/dokumenty/n/170884/karta, dostęp 20.01.2019.

Myczkowski Z., Siwek A. 2017, Park Kulturowy Nowej Huty - nowa formuta ochrony urbanistyki $i$ architektury 2. potowy XX wieku / Cultural Park Nowa Huta - a new formula for the protection of urban planning and architecture of the 2nd half of the 20th century, "Wiadomości Konserwatorskie" / "Journal of Heritage Conservation”, nr 49/2017, s. 113-124.

Park Kulturowy Nowa Huta. Informator Konsultacyjny 2017, Wydawnictwo Gminy Miejskiej Kraków, Kraków

Radłowska R., Kozik R. 2008, Kto się boi Nowej Huty, „Gazeta Wyborcza - Kultura” z dn. 06.02.2008, http://wyborcza.pl/1,75410,4901763.html, dostęp 13.09.2019.

Wallis A. 1979, Informacja i Gwar, Państwowy Instytut Wydawniczy, Warszawa.

Wallis A. 1990, Socjologia przestrzeni. Wybór prac, Niezależna Oficyna Wydawnicza, Warszawa.

Wiśniewski M. 2018, Szpital im. Stefana Żeromskiego i okolice, [w:] J. Klaś (red.) Nowa Huta, Architektoniczny Portret Miasta drugiej potowy XX wieku, Wyd. Ośrodka Kultury im C.K. Norwida - Instytucja Kultury Miasta Krakowa, Kraków, s. 32-39.

\section{Strony internetowe:}

Charakterystyka poszczególnych osiedli Parku Kulturowego Nowa Huta: b.d., https://www.bip.krakow.pl/zalaczniki/dokumenty/n/170831/karta, 20.01.2019.

Ćma atakuje: http://psor.pl/cma-atakuje-bukszpan/, dostęp 10.02.2019.

e-ogródek: http://www.e-ogrodek.pl/a/cma-bukszpanowa-grozny-szkodnik-bukszpanow-rozpo znawanie-i-zwalczanie-19407.html, dostęp 10.02.2019.

Forum ogrodnicze: https://forumogrodnicze.info/viewtopic.php?f=17\&t=106827, dostęp 10.02.2019. Kraków będzie świętowat w Nowej Hucie: https://niezalezna.pl/260261-krakow-bedzie-swietowal -w-nowej-hucie, dostęp 01.03.2019

Krakórw.pl dodaj do ulubionych - nowohuckie podwórka: https://www.youtube.com/watch?v=K4D uAY7es0Q\&index=40\&list=PLONALu7QVIwLBkmB8NSArigEWvMlq5LN3, dostęp 23.01.2019.

Krakow.pl dodaj do ulubionych: (wszystkie odcinki) https://www.youtube.com/watch?reload $=9 \& v=\mathrm{jXUi} Z \mathrm{jvXeYQ} \&$ inde $=55$ \&list $=$ PLONALu7QVIwLBkmB 8NSArigEWvM lq5LN3, dostęp 04.01.2019. 
Magiczny Kraków: https://www.krakow.p1/instcbi/1302,inst,11103,821,instcbi.html, dostęp 10.02.2019.

Nowa Huta miastem?: https://www.tvn24.p1/krakow,50/nowa-huta-miastem-mieszkancy-robia -festiwal,306260.html, dostęp 10.01.2019.

Nowa Huta wolnym miastem?: https://dziennikpolski24.pl/nowa-huta-wolnym-miastem-krak ow-na-to-nie-pozwoli/ar/3205772, dostęp 10.01.2019.

Nowa Huta na starych zdjeciach: https://pl-pl.facebook.com/pages/category/Community/Nowa -Huta-na-starych-zdj\%C4\%99ciach-257971484352971/, dostęp 15.02.2019.

Park Kulturowy Nowa Huta: https://www.bip.krakow.pl/?dok_id=81995, 14.01.2019

Pierwsze osiedla w Nowej Hucie: http://www.nhpedia.pl/pierwsze_osiedla_w_nowej_hucie.html, dostęp 10.02.2019.

Przysztość ROD : http://krakow.pl/aktualnosci/200007,30,komunikat,jaka_przyszlosc_czeka_og rody_dzialkowe_html, dostęp 26.02.2019.

Spotkajmy się na podwórku: https://zzm.krakow.pl/aktualnosci/529-spotkajmy-sie-na-podworku -rewitalizacja-nowhuckich-podworek.html, dostęp 10.01.2019.

ZZM Kraków: https://zzm.krakow.pl/aktualnosci/485-proba-ratowania-cennych-bukszpanow. html, dostęp 10.02.2019. 